By MABEL L. CONAT

\title{
Objectives for Today
}

A Message from the President of A.C.R.L. $\mathrm{A}^{\mathrm{OR}}$ SOLID ACCOMPISHMENT in any field I of endeavor goals must be set, both near and distant. For a clear statement of long-term objectives for college, university, and reference libraries, we cannot do better than to turn back to the objectives Louis Round Wilson proposes in his "Challenge of the I930's to the I940's"1 and also to "The Program of the Association of College and Reference Libraries; A Report by the Policies Committee."2 Embodied here are the recognized professional aims which must not be lost sight of in the exigencies of the present.

Today we are called upon to make a contribution outside and beyond the immediate concerns of professional programs of development. One of the cherished principles in American library tradition has been that libraries should gather and make available impartially, material on both sides of controversial issues. Some of us leaned over backward in trying to achieve strict neutrality and have interpreted this principle to mean that we should never take a positive attitude in presenting and stressing any one side. According to the report of the survey of college and university libraries in the national defense program conducted a year ago by the A.C.R.L. Committee on $\mathrm{Na}$ tional Defense Services:

\footnotetext{
${ }^{1}$ Collcge and Research Libraries I: $130-3 \mathrm{I}$, March, r 940 .

${ }_{2}^{2}$ College and Research Libraries $2: 29 \mathrm{I}-300$, September, I94I.
}

A majority believed that the college library could not make a significant contribution on its own, and a conservative tendency dominated the comments regarding the adoption of a positive and vigorous attitude in trying to interest people concerning the problems around them. The library was generally regarded as having met its responsibility if it made available materials on all aspects of these problems. ${ }^{3}$

The national picture has sharply altered since those pre-Pearl Harbor days, and it is doubtful that this statement represents now the attitude of thoughtful college librarians. Many scholarly libraries are performing significant war services, acting as information centers, providing materials to aid in research projects related to the war effort, and in addition attempting to carry on normal activities in spite of reductions in staff and budgets.

On every hand we are told that "books are weapons" and that "books can help to decide the peace." According to Edgar Ansel Mowrer, "whether we get a temporary peace or a lasting peace, a foolish peace or a peace of discernment ... . will result very largely from the kinds of books our people read between now and the day the peace congress (if there is one) gets going." Do we, the custodians and handlers of books, believe these statements?

\footnotetext{
3 Wilson, Eugene $H$. "Survey of Libraries in Colleges and Universities Which Are Giving Engineering Defense Training Courses." College and Research Libraries $3: 30$, December, 1941.

4 Mowrer, Edgar Ansel. "Informing the Citizen in a World at War." A.L.A. Bulletin 36:455, July, I 942 .
} 
And if we do, do we act.as if we believed them? To so marshal our forces that they contribute to the winning of the peace will require much effort and very likely new attitudes on our part.

\section{Accelerated War Program}

Because of the accelerated war program in our educational institutions and elsewhere, there is little time or opportunity for students, faculty, or laymen to become familiar with all the important discussions of the war and postwar problems that are coming from the presses. It therefore becomes a signal duty for librarians to direct attention to the most significant and thought-provoking publications for him who runs and who must run. Some of us may need to make room in our personal reading for these books so that we can discuss them with discrimination born of personal knowledge. The important task is to help build for the future now-to stress the books that will clarify the issues and promote a fuller understanding of the cultural achievements, the needs, and the hopes of other peoples.

One of our university presidents recently said :

This is not merely a war-it is the greatest revolution civilization ever experienced. ...W We are to have a new social order. Unless our young people are trained to understand the new order and to shape it according to the principles for which they are fighting, there is little sense in continuing the struggle. If there ever was a time when students should have access to accurate information and sound advice, free from hysteria, this is such a time.

Librarians in educational institutions cannot escape the responsibility for the extracurricular reading of the students today, many of whom will be the leaders tomorrow. Honest, unprejudiced, and authoritative materials must be at hand where the students cannot but be attracted to them-materials that will contribute to an intelligent understanding of events, of the changes wrought by modern science, making of the world one neighborhood, and of the necessity of settling postwar problems in terms of basic human needs, if we are to have a permanent peace.

\section{A.L.A. Wartime Policy}

Unreservedly we subscribe to the A.L.A. wartime policy recommendation "that every library give the greatest possible emphasis for the duration of the war to those materials and services which will give people the facts and ideas that will enable them to make intelligent decisions. ..."5 To give concrete direction to this aim, the Association of College and Reference Libraries has a Committee on Wartime Activities under the aggressive chairmanship of Charles Harvey Brown. We look forward with confidence to the results of its endeavors and bespeak your full cooperation and support in achieving them.

B A.L.A. Bulletin 36:428, July, I942. 